\title{
LITTLE BOOK, BIG WAVES: THE EPISTLE OF JAMES AND GLOBAL STEWARDSHIP IN BIOETHICS
}

\author{
Lora Jean Brake ${ }^{1)^{*}}$ \\ 1) Alumna Master of Arts Bioethics, Trinity International University Deerfield, Illinois, USA \\ $\left.{ }^{*}\right)$ Author's Correspondence: albrakecma@gmail.com
}

\begin{abstract}
At first glance the twenty-first century arena of biotechnology and bioethics seems worlds away from the practical concerns of the first century outlook of the New Testament book of James. A closer look, however, reveals that the issues that James addresses have applications to challenges in bioethics. This article will give an overview of James and examine James' teaching on wealth, poverty, and generosity and its import for the issue of global stewardship in bioethics. Stewardship concerns both a Christian's care and management of time, talents, and treasures. Faithful use of the resources God has given demonstrates the fruitful faith that James writes of in his epistle. The idea of global stewardship, though "stewardship" as a term is more used by Christian ethicists, reflects an emerging discussion in bioethics regarding the need to address the inequities present between the money and time spent on biotechnology in some of the world in proportion to the money spent on meeting the basic healthcare needs of the poor of the entire world. This New Testament epistle gives clear indications of how the Christian is to view wealth and how the Christian is to respond to poverty. James, though a comparatively small book, sends a crucial message across the years that should greatly impact how Christians view stewardship in terms of global healthcare needs.
\end{abstract}

Key words: James, stewardship, bioethics, biotechnology, wealth, poverty

Sekilas kemajuan bioteknologi dan bioetika di abad ke 21 tampaknya berbeda jauh dengan persoalan praktis di abad pertama dalam kitab Perjanjian Baru, surat Yakobus. Namun jika diperhatikan dengan seksama, isu-isu yang ditekankan oleh Yakobus memiliki banyak terapan untuk tantangan bioetika. Artikel ini akan memberikan uraian singkat mengenai surat Yakobus dan mengkaji pengajaran Yakobus mengenai kekayaan, kemiskinan, dan kemurahan hati, dan sumbangsihnya untuk isu penatalayanan secara global dalam bioetika. Penatalayanan menekankan kepedulian Kristen dan manajemen waktu, karunia-karunia, dan kekayaan. Kesetiaan menggunakan sumber daya yang diberikan Allah untuk menyatakan iman yang berbuah yang dituliskan Yakobus dalam suratnya. Ide penatalayanan secara global banyak digunakan, walaupun istilah "penatalayanan" lebih banyak digunakan oleh para pakar etika Kristen, mencerminkan diskusi yang berkembang dalam bioetika berkaitan dengan kebutuhan untuk mengatasi kesenjangan antara uang dan waktu yang 
dihabiskan di bidang bioteknologi di beberapa tempat di dunia dengan jumlah uang yang dihabiskan untuk memenuhi kebutuhan dasar di bidang kesehatan bagi orang miskin di seluruh dunia. Surat Perjanjian Baru ini memberikan petunjuk yang jelas tentang bagaimana orang Kristen memandang kekayaan dan menanggapi persoalan kemiskinan. Yakobus dalam suratnya yang relatif kecil, mengirimkan sebuah pesan penting dari masa ke masa yang seharusnya berdampak besar bagi orang Kristen dalam melihat penatalayanan bagi kebutuhan kesehatan global.

Kata-kata kunci: Yakobus, penatalayanan, bioetika, bioteknologi, kekayaan, kemiskinan.

\section{Introduction}

At first glance the twenty-first century arena of biotechnology and bioethics seems worlds away from the practical concerns of the first century outlook of the New Testament book of James. ${ }^{1}$ A closer look, however, reveals that the issues that James addresses have applications to challenges in bioethics. For instance James writes, "If a brother or sister is without clothing and in need of daily food, and one you says to them, 'Go in peace, be warmed and be filled,' and yet you do not give them what is necessary for their body, what use is that?" ${ }^{2}$ How does this first century quote speak to a world where in 2014 the biotechnology industry spent about $\$ 35.4$ billion on research and development, ${ }^{3}$ while at the same time millions of people are living in a state of poverty? If one takes into account aspects other than just how much income a person makes, such as factors related to health, education, and living conditions, it is not millions of people living in poverty, but about 1.6 billion people. ${ }^{4}$ While some of that research may have the goal of helping those in poverty, some of it is for applications that will remain far out of the reach of those struggling to for their daily needs. This article will examine James' teaching on wealth, poverty, and generosity and its import for the issue of global stewardship in bioethics. The idea of global stewardship, though "stewardship" is grounded in a distinctly Christian ethic, reflects an emerging discussion in bioethics regarding the need to address the

${ }^{1}$ This article is a modified version of the author's paper that was written in the Fall of 2007 for the class "Foundations of Integrative Thought" in the Masters in Bioethics Program at Trinity International University, Deerfield, Illinois, USA.

Jas 2:15-16.

3 Asher Mullard, "Robust Biotech Sector Increases R\&ED Spend", Nature Reviews Drug Discovery, (July 1, 2015). Accessed March 21, 2016. http://www.nature.com/nrd/ journal/vl4/n7/full/nrd4687.html

${ }^{4}$ Tanya Basu, "How Many People in the World are Actually Poor?", The Atlantic. Accessed March 21, 2016, http://www.theatlantic.com/business/archive/2014/06/wevebeen-measuring-the-number-of-poor-people-in-the-world-wrong/373073/ 
inequities present between the money and time spent on biotechnology in the world in proportion to the money spent on meeting the basic healthcare needs of the poor of the entire world. This New Testament epistle gives clear indications of how the Christian is to view wealth and how the Christian is to respond to poverty. James, though a comparatively small book, sends a crucial message across the years that should greatly impact how Christians view stewardship in terms of global healthcare needs.

\section{Overview of James}

Before addressing these issues, a general overview of James and its teaching is necessary. This book's practicality, brevity, and word pictures and illustrations appeal to readers. Therefore, though some scholars have criticized James and have questioned its place in the canon, it has remained a favorite book of Christians. ${ }^{5}$ James addressed issues of wealth and poverty, wisdom, and suffering and trials. Traditionally, James the Just, the half-brother of Jesus is identified as the author of this work. Some contemporary scholars, however, not satisfied with this account of the matter, have posited various theories of authorship. ${ }^{6}$

Despite scholarly debate over the authorship and date, no sufficient arguments exist to cast doubt on the authorship of the letter by James the Just, brother of the Lord, probably sometime before the Jerusalem Council of AD 49. AD 49 is the upper limit for the early date because of the Jerusalem Council recorded in Acts 15. It would have been odd for James not to have alluded to this had he written the letter after he Council. ${ }^{7}$ The letter could not have been composed later than AD 62, for

\footnotetext{
5 Douglas J. Moo, The Letter of James, The Pillar New Testament Commentary (Grand Rapids, MI/Cambridge, U.K.: William B. Eerdmans, 2000), 1-2.

${ }^{6}$ The theories include: 1) Another James besides the brother of Jesus authored the letter, Luke Timothy Johnson, The Letter of James: A New Translation with Introduction and Commentary, The Anchor Bible Vol. 37A (New York: Doubleday, 1995), 93. 2) James is a pseudonym used by an author of later date than that of James the Just, and 3) James the Just was the oral or written source for the text, but a later editor reconfigured or expanded his thoughts. Peter Davids' conclusions lean in this direction. He notes that the internal and external evidence support the idea that James the Just is the source of the material. One of reasons Davids posits a redactor is because of the Greek idiom that is used in the text; he thinks that James either had help editing the text or that someone else edited the text at a later point in time. Thus he cites an early date for the original material, AD 40-49. Peter Davids, Commentary on James, New International Greek Commentary (Grand Rapids, MI: Eerdmans, 1982), 2-3, 7-22.

${ }^{7}$ Robert H. Gundry, A Survey of the New Testament, 4th edition (Grand Rapids, MI: Zondervan, 2003), 477. Davids, 22.
} 
at that time James was martyred. ${ }^{8}$ Academic debate also surrounds the determination of the audience and historical circumstances of the book of James. James belongs to the group of New Testament writings known as "General" epistles because there is no specific group, location, or person that is named as the recipient of the letter, though differing accounts of an intended audience and their particular situation have been suggested. ${ }^{9}$ Some have argued that the "twelve tribes" is a metaphorical reference to the Jewish and Gentile church as the new Israel. ${ }^{10}$ More evidence, however, seems to support the view that James wrote to Jewish Christians that were living outside of Israel (1:1). ${ }^{11}$ Even if the letter was written to Jewish Christians scattered outside of Israel, the general instructions that James gives would have been applicable in a predominantly Gentile church.

Commentators differ as to whether or not James was writing in response to particular problems or whether he was writing to instruct about general problems that happen to arise in a believing community. Richard Bauckham argues the latter position that James' purpose was to give instructions to Jewish Christians living outside of Israel about standard problems that might arise. ${ }^{12}$ Certain features of the letter, however, indicate that James is, at least in some instances, addressing specific issues. For instance, in his vivid warning about the power of speech, James admonishes his audience that the same mouth that blesses God should not curse man, who is made in God's image, "My brethren, these things ought not to be this way" (Jas. 3:9-10). Furthermore, James

${ }^{8}$ Moo, 26-27; Gundry, 477. Other commentators agree that the internal and external evidence point to an early date and authorship by James the Just; Johnson, 121; James Adamson, The Epistle of James, The New International Commentary on the New Testament, (Grand Rapids, MI: Eerdmans, 1976; reprint, Grand Rapids, MI; Eerdmans, 1984), 18. (page citations are to reprint edition). Douglas Moo, while in whole agreement with the early dating of James, argues that some of the alleged idiosyncrasies of the text, such as the use of Greek idiom, do not rule out that James was in charge of the text from "soup to nuts." Moo, The Letter of James, 21-22. Even our own literary compositions at times contain phrases peculiar to our generation or phrases adopted from other languages. I find it somewhat ironic that in the same paragraph that Davids states his conclusions he uses the German Sitzim Leben. My point here is that Davids is very naturally adopting a German phrase that he has learned through his biblical studies; he assumes that his readers will understand this, even if they are not fluent in the German language. It seems that James' world was inhabited by several languages, including Greek, and it may have been very natural of him to adopt Greek expressions which his readers would probably have understood.

${ }_{9}^{9}$ Gundry, 474. Moo, 6.

${ }^{10}$ Ibid., 476.

${ }^{11}$ Moo,4.; Adamson, 64; Gundry, 476. cf. Richard Bauckham, James: Wisdom of James, Disciple of Jesus the Sage, New Testament Readings (London/New York: Routledge, 1999), $14-16$.

${ }^{12}$ Bauckham, 26-28. 
exhorts that it is not partiality to the wealthy that exhibits faith in Christ, but exhibiting neighbor love to those in need that substantiates a verbal confession of faith (2:1-26). He also reminds them that the very ones to whom they are showing partiality are the ones that oppress them, take them to court, and blaspheme the name of Christ. This seems to point to a particular issue with which his audience struggled. ${ }^{13}$ Moo gives a balanced conclusion to the nature and importance of the setting of the book of James:

[w]hile the social and historical situation of the readers may help us understand the problems they are dealing with, those problems are ultimately both more general and more basic than the immediate situation. The displaced status of these Jewish Christians has brought to the surface some basic spiritual issues; and it is to these spiritual issues that the author directs his exhortations. ${ }^{14}$

It is not necessary, therefore, to labor over a detailed reconstruction of the social and historical milieu of this epistle in order to understand and apply it. The issues involved are issues that would have been struggles of believing communities in general.

Thus far the term "letter" has been used to identify this exhortatory work of James, but James' actually lacks the habitual salutations, mention of fellow workers and travel itinerary that traditionally indicate the work as an epistle. ${ }^{15}$ Therefore, the identification of a genre for the book of James is still yet another area of scholarly discussion. This book has been variously identified as a diatribe, paraenesis, protrepsis, wisdom, and an epistle. ${ }^{16}$ It defies distinctive identification with just one of these categories. One of the most reasonable suggestions is to categorize James "... as a sermon or homily. The author, separated from his readers by distance, cannot exhort them in person or at length. So he must put his preaching into written form, using a letter to cover briefly the main points that he wants them to understand." ${ }^{\text {17 }}$ In this short epistolary sermon James makes use of various literary elements to focus and elaborate on the topics of suffering and testing in the context of

13 Some commentators see very specific social and historical circumstance evidenced in the letter, such as James' teaching on wisdom in speech referring to the "...complaining, bitterness, and party struggles. .." that were a result of the tension between the Zealots, who championed the poor, and the wealthy pro-Roman contingent. Davids, 33-34. Though this could be the case, the entire book cannot be seen through a "narrowly socioeconomic" interpretive lens, Moo, 24.

${ }^{14}$ Moo, 25.

${ }^{15}$ Moo, 6.

${ }^{16}$ Johnson, 17-24; Moo, 8; Gundry, 478; Davids, 23.

${ }^{17}$ Moo, 8-9; cf. Adamson, 20; Davids, 12; and Johnson, 24. 
difficult circumstances, wisdom in inner attitudes that govern verbal response to outward circumstances, and obedience to the word especially in regards to wealth, poverty, and generosity. James' overarching concern that the believing community embody friendship with God, rather than the world, is the unifying thread that holds these themes together $(1: 27 ; 2: 23 ; 4: 4){ }^{18}$

James conveys these typical spiritual issues in a wealth of literary flair. ${ }^{19}$ The author makes use of simile $(1: 6,10,23-24)$ and metaphor (3:6, $8 ; 4: 14)$. The epistle also contains proverb-like statements (1:19-20; 2:13, $17,26 ; 3: 8)$ and illustrations $(3: 3-5,7,1-12)$ that contribute to the wisdom features of the text. James also uses people from Israel's history to enhance his arguments: Abraham, Rahab, Job, Elijah, and the prophets. Not only does James use the prophets as an example, but he himself lends a prophetic tone to his writing at times. The "You adulteresses" in the prophetic-like passage of 4:1-5 is especially reminiscent of Old Testament prophetic literature. ${ }^{20}$ This epistle also shares commonalities with other New Testament writings such as John's, especially l John, and 1 Peter. ${ }^{21}$ Perhaps the most unique literary feature of the book of James is the number of allusions to Jesus' teachings.

No other NT writer refers to Jesus' teachings as much as James. For example, 3:18 seems to recall Jesus words in Matt 5:9 "Blessed are the peacemakers ..." and 5:10-11 recall Jesus words about persecution in Matt 5: 10-11. As Davids notes "... the whole book exudes the Sermon on the Mount." 22 James also shares commonalities with literature outside of the biblical text. Scholars note that James evidences parallels to GrecoRoman moralists, such as Seneca, Jewish literature, such as Philo's writings, and non-canonical Christian texts, such as The Shepherd of Hermas. ${ }^{23}$ James' skillfully wrought epistle is not an anomaly among ancient writings, but utilizes familiar forms and ideas parallel both to its religious and cultural heritage. The allusions to Jesus' teachings and the literary craftsmanship of the letter remind the readers of what they have been taught and help them to better remember the instructions James gives.

\footnotetext{
${ }^{18}$ Moo, 24-25, 45; Johnson, 21.

${ }^{19}$ The observations in this section are from the author's personal study of James. Unless otherwise noted the citations indicate confirmation of the author's observations.

${ }^{20}$ Gundry, 478; Adamson, 19. 5:1-6 echoes the book of Amos.

${ }^{21}$ Johnson, 48-57.

${ }^{22}$ Davids, 16; Moo, 7; Gundry, 477.

23 Johnson, 27-29, 34-46, and 66-79. In the case of The Shepherd of Hermas commentators note that it is likely that the author was familiar with and used James. Johnson, 79; Moo, 3.
} 
With all the craftsmanship in composing addresses about individual issues, it is interesting that Moo notes that there is no "clear organization" or readily apparent relationship between one topic and another. He cautions against imposing a contemporary literary analysis on an ancient text. Indeed, modern scholarship has come up with a plethora of outlines for James. ${ }^{24}$ Even so, it seems that some general organizational structure, such as Luke Timothy Johnson suggests, emerges from the text rather than is imposed upon it. Johnson argues that the first chapter introduces the themes that are then elaborated in the rest of the letter: 1:5-7 (concerning prayer of faith) is expanded in 5:13-18; 1:9-10 (real situation of wealthy and poor) is expanded in 2:1-7 and 4:13-5:6; 1: 2-4, 12 (perseverance in testing) is expanded in 5:7-11; 1:1218 (evil desire in opposition to God's gift) is expanded in 3:13-4:10; 1:1920 (use of speech) is expanded in 3:1-12; 1:22-27 (obligation to externalize faith) is expanded in 2:14-26. Johnson also comments that in the final verses, 5:19-20, James' encouragement to the readers to exhort others as he has exhorted them is a fitting conclusion. All of these motifs are bound together by their exhortations to live a life oriented toward God rather than toward the world. ${ }^{25}$

The practical teachings concerning prayer, suffering, poverty, wealth, generosity, wisdom, faith, and deeds, ${ }^{26}$ form part of and are supported by the theology inherent in the book of James, “. . . James moral discourse is deeply embedded in the theological convictions of Judaism and the nascent Christian community." 27 The epistle's teaching on poverty, wealth, and generosity echoes both the teachings of the Old Testament ${ }^{28}$ and Jesus. Taking care of the orphan and widow (1:27) and a fellow believer in need (2:15-16) are essential identifying marks of faith: "This is pure and undefiled religion in the sight of our God and Father, to visit widows and orphans in their distress and to keep oneself unstained by the world." The description of the transitory nature of wealth and exhortation to refrain from showing partiality to the wealthy (1:9-11 and 2:13) indicate the author's concern that his readers have appropriate attitudes and actions concerning worldly riches. The Old Testament and Jesus' teachings also ground James' instructions about prayer, suffering, and wise control of speech. The exhortation concerning speech is a reflection of the abundant teachings in Proverbs, such as Prov 10:19, and

\footnotetext{
${ }^{24}$ Moo, 7. Moo does indicate several themes in James and agrees there is an overall unifying theme, 44-46.

${ }^{25}$ Johnson, 14-15.

${ }^{26}$ The thematic list is dependent in part upon the themes distinguished in Davids, 34-57 and Moo, 26-46.

${ }^{27}$ Johnson, 160.

${ }^{28}$ e.g. Isa 1:16-17, 10:2, Amos 2:6, 6:41; Hosea 12:7
} 
Jesus teaching about careless words in Matt 12:33-37. James words concerning faith and prayer (1:6-7) parallel Jesus' use of the withered fig tree as an object lesson about faith without doubt (Matt 21:21). Furthermore, in 5:17-18 James specifically cites Elijah as an example of the prayer of faith. The prophets as well as Job (5:9-10) are brought forth as examples of patient endurance of suffering; suffering that Jesus himself predicted (Matt 24:9-14).

\section{James' Teaching on Wealth, Poverty and Generosity}

While each of these areas is worthwhile to explore, the present discussion will focus on the relevance of James teaching on wealth, poverty, and generosity to the emerging discussion in bioethics concerning global health care needs. James makes it clear that it is imperative for Christians to care for the economically disadvantaged, such as the orphan and the widow (1:27), fellow Christians in need (2:1516), and by extension any person who has a need (2:8) ${ }^{29}$ Furthermore, James' warnings about the transitory nature of the rich and their wealth (1:9-1l and 5:1-6) teach Christians that security lies in eternal treasures not worldly wealth. Thus, James' teachings on wealth, poverty, and generosity demonstrate that bioethics needs to focus not only on ethical dilemmas surrounding cutting-edge biotechnologies, such as gene therapy, $\mathrm{IVF}^{30}$, enhancements, and cloning, but also on basic health care needs of the world's poor. ${ }^{31}$ From a Christian perspective, James speaks to issues of global stewardship in bioethics.

The Christian concept of stewardship is grounded in the Creation narrative of Genesis 1 and 2. Looking to the Old Testament for guidance in understanding James is appropriate, for the thought in this epistle is greatly informed by the Old Testament as well as Jesus' words. Genesis 2:15 records, "The Lord God took the man and put him into the garden of Eden to cultivate it and keep it." ${ }^{32}$ The Hebrew word used here for cultivate, abad, and keep, shamar indicate the work and care God desires humans to have in relationship to the creation. Shamar is used elsewhere to describe Abel's work (Gen. 4:9), the safekeeping of persons (Gen.

${ }^{29}$ Though James identifies those in 2:15-16 as fellow believers, the earlier reference (2:8) to the Old Testament command to love one's neighbor and Jesus' exposition of it in the parable of the Good Samaritan extends the command to caring for those in need regardless of religious affiliation.

${ }^{30}$ In vitro fertilization. In Indonesian: "bayi tabung".

${ }^{31}$ It is also important to note that there exist disparities in the U.S. as well. This paper, however, will focus on the global context.

${ }^{32}$ C. Ben Mitchell, Edmund D. Pellegrino, Jean Bethke Elshtain, John F. Kilner, and Scott B. Rae, Biotechnology and the Human Good (Washington D.C.: Georgetown University Press, 2007), 25. 
28:15, 20), and the service of priests to God (Lev. 8:35; Num. 1:53, 18:5). ${ }^{33}$ Stewardship concerns both Christians' careof creation and management of time, talents, and treasures. ${ }^{34}$ Faithful use of the resources God has given them demonstrates the fruitful faith that James speaks of in chapter two.

In addition to the biblical concept of stewardship, the kingdom goals of justice and love ${ }^{35}$ also ground James call to care for the orphan and widow, renounce partiality, meet the physical needs of others, and his warning of the fleeting nature and misuse of worldly riches. James' call to love is more explicit (cf. 2:8) while the exhortation to justice is implicit in the directives and cautions just mentioned. ${ }^{36}$ Proper stewardship exercised through justice and love are supposed to be hallmarks of God's people. Though differing in definition, justice and love are inextricably linked in practice. ${ }^{37}$ Biblical love is multifaceted in its manifestations. It includes feeling with others and partaking of their oppression, acting on behalf of others to deliver, inviting others into "...community with freedom, justice and responsibility for the future", calling to account those who reject others. It goes to the extreme of loving enemies. Love is found at its most profound and essential expression at the cross. "But God demonstrates His own love toward us, in that while we were sinners, Christ died for us." ${ }^{39}$ God's love for people enables them to love Him and to love each other. ${ }^{40}$ Love is not a vague sentiment that Christians try to foster for those that are "less fortunate" ${ }^{41}$; love very much involves actions that are other-oriented. An essential component of this love is care for the physical needs of others $(2: 1-17)$.

Just like love, justice is more than an abstract concept or feeling, it is "...the activity of putting right a disordered or disproportionate state of

${ }^{33}$ C. Ben Mitchell, Edmund D. Pellegrino, Jean Bethke Alsatian, John F. Kilner, and Scott B. Rae, Biotechnology and the Human Good (Washington D.C.: Georgetown University Press, 2007), p. 25.

${ }^{34}$ Glen H. Stassen and David P. Gushee, Kingdom Ethics: Following Jesus in Contemporary Context (Downers Grove: InterVarsity Press, 2003), 424-446.

${ }^{35}$ Ibid., 325-365.

${ }^{36}$ Due to space and the subject matter, the exegesis of justice will be a bit fuller than that of love. I will be going back to the Hebrew for an understanding of justice. This is appropriate in light of how much both Jesus' teachings and James' letter are based on the Old Testament.

${ }^{37}$ Stassen and Gushee, 325.

${ }^{38}$ Ibid., 333-344.

${ }^{39}$ Romans 5:8.

${ }^{40}$ I John 4: 7, 10-11.

${ }^{41}$ Stassen and Gushee, 21-22, and 94. 
affairs." ${ }^{42}$ Stassen and Gushee note that in Old Testament there are two notions of justice: '...tsedaqah means community-restoring justice, and mishpat means judgment according to right or rights, and thus judgment that vindicates the right especially of the poor and powerless." ${ }^{43}$ Thus biblical justice entails more than just procedural justice which guards people from "fraud, theft, and violence." ${ }^{44}$ Ron Sider also comments on the "restoration to community" aspect of justice. He points to Leviticus 22:35-36 and argues that we are to make the poor strong so that they can become involved in the community. While food and clothing are essentials for this they also need to have their ability to be a productive part of the community renewed. ${ }^{45}$ Thus there both exists the responsibility to protect the rights of the poor and the responsibility to "put to right" factors in the community so that the poor are able to participate in the community and thus have an opportunity to transition to a more prosperous existence. It is appropriate give emergency assistance, but it is also necessary to help identify assests inherent in the community or the person in order to help the individual and their community thrive. ${ }^{46}$ People will find restoration in a community where there is active practice of both mishpat and tsedaqah.

Also present in the Old Testament Scriptures is a "cycle of care and responsibility." The poor cry out to God. The God who cares for them, hears them. The laws God had put in place demanded that Israel care for the poor and vulnerable. "In effect care for the poor serves as a leading indicator of justice in Israel." J7 James echoes this indicator and the kingdom goals of love and justice when he remarks in 1:27, "Pure and undefiled religion in the sight of our God and Father is this: to visit orphans and widows in their distress, and to keep oneself unstained by the world."

Jesus taught and modeled this kind of love and justice. James would have been very familiar with Jesus' modeling of these and indeed they form an important backdrop for his letter. Expressing compassion for the

\footnotetext{
42 Donald A. Hay, Economics Today: A Christian Critique (Grand Rapids, MI: William B. Eerdmans Publishing Company, 1991), 79.

${ }^{43}$ Stassen and Gushee, 345.

${ }^{44}$ Ibid., 74. cf. Hay, 79-89.

${ }^{45}$ Ronald J. Sider, Just Generosity: A New Vision for Overcoming Poverty in America, 2nd edition (Grand Rapids, MI: Baker Books, 2007), 72-73.

${ }^{46}$ For a thorough discussion of this see: Steve Corbett and Brian Fikkert, When Helping Hurts: How to Alleviate Poverty Without Hurting the Poor or Yourself (Chicago: Moody Publishers, 2009).

${ }^{47}$ Kent A. Van Til, Less Than Two Dollars a Day: A Christian View of World Poverty and the Free Market (Grand Rapids, MI/ Cambridge, UK: William B. Eerdmans Publishing Company, 2007), 74.
} 
widow of Nain, he raised her son from the dead. ${ }^{48}$ He commanded against storing up earthly treasures that would not last the test of eternity. ${ }^{49}$ He warned that a focus on wealth harms the seed of faith ${ }^{50}$ and that "treasure barns" are not ultimate security for the soul. ${ }^{51}$ James would have been very familiar with Jesus' modeling of these and indeed they form an important backdrop for his letter (cf. James warning against those who trust in worldly wealth and treat others in an unjust economic manner, 5:1-6 with Jesus words about the transitory nature of earthly treasure, Matt 6:19-21).

Not only are love and justice set before Christians as commands, but the Lord who commands displays those very characteristics in His nature and actions: "Righteousness and justice are the foundation of Your throne; Lovingkindness and truth go before You." ${ }^{52}$ Scripture testifies to God's love and justice, as well as His special concern for the poor. $^{53}$

Bioethicists communicating in the "secular" realm do not discuss the economic disparities present in the world in terms of "stewardship" or love, but they do use concepts such as human rights and justice. The biblically defined view of justice is somewhat congruent with the cultural idea of distributive justice. Distributive justice is concerned that the concrete outcomes of policies and actions are just. ${ }^{54}$ This partial congruence, therefore, creates an avenue for conversation and action on global issues with those who do not share a biblical worldview. In these endeavors, however, Christians need to stay grounded in friendship with God, not the world.

\section{James' Implicit Theology}

Other aspects of James theology are not so directly stated as his teachings on riches, poverty, and generosity, yet they form the framework upon which the practical teachings rest. The most important aspect upon which James' ethics rest is his understanding of God. Moo comments that God's oneness, jealousy, and grace are three essential facets of God's character expressed in this letter. God's oneness refers to

${ }^{48}$ Luke 7:11-17.

${ }^{49}$ Mt. 6:19-21; Luke 12:33-34.

${ }^{50}$ Mt. 4:18-19, Mark 13:22.

${ }^{51}$ Luke 12:15-21.

${ }^{52}$ Psalm 89:14. In this verse (v. 15 of the Hebrew text) the tsedaqah of the Hebrew is translated as "righteousness" as Stassen and Gushee note of many translations. Mishpat is translated "justice." Present is this verse, therefore, are both notions of justice. Kingdom Ethics, 345.

${ }^{53}$ Isa 11:1-4 Is. 26: 2-10; Mt. 23:23. Van Til, 74-75.

${ }^{54}$ Van Til, 6. 
God's constancy, a characteristic that should be reflected in the lives of believers as well. God's jealousy relates to the idea that His people are to be whole-heartedly devoted to God. While God requires the obedient fidelity of believers, he also gives grace to those who humble themselves before Him. ${ }^{55}$ The book's Christology, though explicitly minimal, is implicitly substantial in underpinning and understanding his work. James' Christology is an "assumed" Christology; he does not write a complete account of his understanding of who Christ is. That the epistle's teachings are thoroughly connected to the teachings of Jesus indicates that James thinks that Jesus' words should direct the steps of the community to whom he is writing. James also views Christ as "the exalted Lord in heaven" and "the coming Lord and judge."

The last reference to Christ informs James' view of eschatology. James conveys a sense of imminence concerning the return of the Lord, including the advent of judgment and justice. The letter also reflects the biblical "now... but not yet" of the kingdom of God. James ethical directives point the way to living a life pleasing to God now that is essential to preparation for the Lord's return. ${ }^{57}$

\section{Canonicity}

The practical teaching and profound theology, explicit and implicit, that James expresses through vivid language and literary craftsmanship exhibit the importance of James' place in the canon. The canonical status of this epistle, however, has not always been secure. Though evidence exists that early Christian writings made use of James, it was not until the fourth century AD that both the eastern and western church accepted it. ${ }^{58}$ During the Reformation others arose that doubted James; the most noted questioner was Martin Luther. Though he used the book of James, he did not place it on equal footing with the other canonical books. Luther thought that James' teaching concerning faith and works was somewhat in opposition to Paul's theology of justification by faith.

This alleged contradiction between James' teaching in 2:14-26 and Paul's teaching on justification by faith highlights another important theological component of the book of James: that of the relationship between faith and works. Though much has been made of the "James and Paul controversy," upon examination no valid grounds for this dichotomy exist. When one reads James alongside the writings of Paul a

\footnotetext{
${ }^{55}$ Moo, 28-29.

${ }^{56}$ Davids, 39-41.

${ }^{57}$ Ibid., 38-39; Moo, 29-30.

${ }^{58}$ Moo, 2-4; Johnson, 127-128. Both Moo (3) and Johnson (128) note that two early Christian writings, I Clement and The Shepherd of Hermas seem to make use of James.
} 
contradictory description of the Christian life does not emerge. In fact, the book of Acts records James' support of Paul's message and mission (Acts 15:13-21, 21:18-26) and Paul does demonstrate concern for outward manifestations of faith (cf. Paul's concern for the Thessalonians' behavior in 1 Thess 4:1-12). James and Paul are not in competition, they are complementary: "James... is not arguing that a Christian must 'add' works to faith; he insists that true saving faith will 'work'." exemplifies James' relationship with Paul well as James' relationship to the entire canon.

The overall theological significance of the book of James consists of the theologically-grounded practical instructions that give the Christian clear direction on how to live a life that is pleasing to God. The "disagreement" between James and Paul is only apparent. Significantly Moo comments,

James has his own contribution to make to our understanding of Christian theology and practice. That contribution... provides an important counterweight to a potential imbalance from reading Paul (or certain of Paul's letters alone ... We can be grateful for the opportunity to read, appropriate, and live out the distinctive emphases of this important NT letter. $^{60}$

Thus, both James and Paul are crucial and complementary parts of the canon. James, through the utilization of Old Testament examples and allusions alongside the embedded teachings of Jesus, demonstrates the continuity of God's redemptive work in the Old and New Testament.

The debate about the place of James in the canon continues in the works of contemporary scholars. Academics have their own questions particularly concerning James' origin. Yet arguments, such as those cited earlier for James' authorship, can effectively establish James authorship and canonical status. ${ }^{61}$ The establishment of James in the canon is vital, for the absence of James from the canon would bereft Christians of impassioned, richly textured instructions on the necessary harmony between attitudes, beliefs, and actions. While Christians could manage to embody a Christ honoring life without the book of James, for James' teachings are found elsewhere in Scripture, its exclusion from the canon would be like missing a savory ingredient for a recipe. One could eat the prepared dish and be filled, but a certain zest and completeness would be missing. 64 .

${ }^{59}$ Ibid., 42; See discussion of this issue in Gundry, 478; Davids, 19-21; Johnson, 58-

${ }^{60}$ Ibid., 6.

${ }^{61}$ Moo, 4-6. 


\section{James and the Twenty-First Century}

James' zest is a crucial component for cultural engagement in the twenty-first century. In miniature form and powerful images it confronts readers with the need for wisdom in making decisions on how to live a life in the world that is oriented toward God, but not of the world. James covers a variety of subjects on living life with a proper attitude in difficult circumstances and in proper relationship with others both in the community of believers and the community of humanity. The transfer of James' teaching to modern society is not difficult for it addresses perennial issues of trials, anger, injustice in social and church relations, the powerful effects of speech, and concerning all of this, the need for wisdom. "Wisdom is the ability to make godly choices in life." ${ }^{63}$ The basic nature of James instructions speaks to any profession in any age, for the need for godly choices has always been present for Christians in all ages and in all professions and disciplines. One such discipline is bioethics, a shortened form of the term "biomedical ethics."Actually bioethics is not just one discipline, but pulls from a variety of disciplines, such as medicine, public policy, philosophy, theology, law, and science to evaluate and discuss (and debate) the ethical issues that arise in application or potential application of medical technology and biological research to human life. Bioethics covers subjects from conception to death, such as In vitro fertilization, cloning, gene therapy, abortion, HIV/AIDS, and euthanasia to name a few. The explosion of biotechnology ${ }^{64}$, however, and its resultant ethical dilemmas that bioethics investigates have created unforeseen challenges, especially to the concept, "What does it mean to be human?" It is imperative that Christians seek God's wisdom both in how to make personal and communal decisions concerning biotechnology, and how to interact with the culture when a divergence of opinion exists.

James makes a unique contribution as a foundation for dialogue with non-Christians concerning social issues in general and bioethics in particular. Johnson notes that James supplies a "bridge" for dialogue about social ethics:

\footnotetext{
${ }^{62}$ Ibid., 24-25.

${ }^{63}$ Gordon D. Fee and Douglas Stuart, How to Read the Bible for All Its Worth, third edition (Grand Rapids, MI: Zondervan, 2003), 225.

"64"Biotechnology" is a general term used to cover a broad array of "...procedures for modifying living organisms according to human purposes", Biotechnology: 〈https://en.wikipedia.org/wiki/Biotechnology〉 URL accessed March 21, 2016. It would take a great deal of space to explain this term in depth, but it is enough for the purposes of this article to indicate, that it has applications in the medical, pharmaceutical, and agricultural fields among others.
} 
The most obvious example is its prophetic condemnation of the oppression of the poor by the exploitive rich. But equally important are the outspoken criticism of discrimination between humans on the basis of appearance; the portrayal of the power and perils of speech; the analysis of the roots of social conflict, war and murder in the logic of envy. ${ }^{65}$

Considering the reality of pluralism in the contemporary context these bridge-building directives in the book of James provide welcome points of dialogue. The dialogue, however, should always take place with the believer firmly rooted in friendship with God without any compromise that would then place the believer in a position of friendship with the world (Jas 4:4).

This bridge-building is especially relevant to oft contentious conversations in bioethics. Several different aspects of James intersect with issues in bioethics: James' teaching on the power of speech and the need for a gentle dialectic in bioethical discussions; ${ }^{66}$ the exhortation concerning endurance in the face of suffering and trials and that suffering is not to be overcome by any and all means; the instruction on the finitude of human existence and its application to the posthuman project; the teaching about the importance of attention to those in a vulnerable economic position; and finally, James' reminder of the coming deliverance of the Lord and its opposition to the view that this life is all there is.

\section{Global Stewardship in Bioethics}

Though James' addresses the inequities present in a first century community of believers, a look at the state of affairs in twenty-first century shows that his admonitions concerning wealth, poverty, and generosity are of great consequence to global stewardship in bioethics. Global stewardship in bioethics raises the question of whether or not we have an obligation to aid those in the world who lack basic necessities such as food and healthcare. Kent A. Van Til notes that more than 40 percent of the people in the world live on less than two dollars a day. Furthermore,

...81 children out of 1,000 die before they reach the age of five; 100 million do not attend primary school. More than a billion people lack access to safe

\footnotetext{
${ }^{65}$ Johnson, 164.

${ }^{66}$ Edmund Pellegrino, Plenary 8. "Changing Times" Neuroethics: the New Frontier. $13^{\text {th }}$ Annual Conference on Bioethics, Trinity International University, Deerfield, IL. July 15, 2006. cf. general statement on the need for "speech ethics" in Bauckham, 204.
} 
water... By our standards, over 40 percent of the world's people lack basic necessities. $^{67}$

The lack of necessities and economic hardship is worsened by the flight of health professionals from these poor nations to nations of greater opportunity. The resources, in terms of money invested for their education and knowledge they gained, are subsequently lost to the nation of origin. In Africa, nations spend $\$ 500$ million dollars a year for education and training of health professionals that go elsewhere to practice. ${ }^{68}$ In the 1980 s over 60 percent of doctors trained in Ghana moved overseas. 188 doctors are present for every 100,000 people in the United States. In vast parts of Africa, however, only one or two doctors are available for every 100,000 people. ${ }^{69}$

Some might claim that these statistics do not paint the whole picture. Though this is true and Donald A. Hay cautions about the need to interpret statistics correctly, he also maintains that they do show that, "A very large proportion of mankind lives in conditions of great personal deprivation. By comparison the inhabitants of the industrial countries live in prosperity and luxury." ${ }^{70}$ Furthermore, it is not just a matter of money for basic healthcare in the U.S. compared against basic healthcare in a Third World country; millions of dollars in the U.S. are spent "treating" conditions that in no way fall under the rubric of basic healthcare. This inequity is not just a "First World vs Third World" problem; even in developing countries there is lavish spending on luxury items in the face of a growing rich-poor gap. For instance this gap is growing wider in Indonesia, a country where there an average of about $\$ 750$ a year spent on new gadgets and wealth enough for some to shell out anywhere from $\$ 1,000-\$ 50,000$ on a designer handbag. ${ }^{71}$

Cosmetic surgery and enhancement technologies are ways that the more wealthy pursue or wish to pursue "treatments" such as breast

\footnotetext{
${ }^{67}$ Van Til, 2.

${ }^{68}$ Ibid., 45.

${ }^{69}$ Norman Daniels, "Equity and Population Health: Towards a Broader Bioethics Agenda," Hastings Center Report 36, no. 4 (2006): 30.

${ }^{70}$ Hay, 250.

${ }^{71}$ Abdurrahman Syebubakar, "Indonesia Witnesses Rising Poverty", The Jakarta Post, October 8, 2015, accessed 21 March 2016, http://www.thejakartapost.com/news/ 2015/10/08/indonesia-witnesses-rising-poverty.html; Karisma Vaswani, "Indonesia's New Mega-rich Spend it Big as Inequality Grows", August 1, 2014, accessed 21 March 2016, http://www.bbc.com/news/business-28570422; Rimba Laut, "Orang Indonesia Habiskan Rp 10 Juta per Tahun untuk Beli Gadget, October 2, 2015, accessed 18 March 2016, http:www.ift.co.id/news/tekno/mobile/orang-indonesia-habiskan-rp-10-juta-pertahun-untuk-beli-gadget.
} 
augmentation and scanning their brains. ${ }^{72}$ This is thousands of miles away from the healthcare dilemmas of the poor all around the world. It is not just that these disparities exist, but that an obscene chasm stretches between the amounts of money even now spent on enhancements compared to the amount spent meeting the basic necessities of life:

The global implications of this maldistribution of humanity's resources must eventually be confronted...Surely sanitation, immunization, and access to necessary medical care ought to take precedence over a superathlete's urges for a few more seconds off the four-minute mile or a new record for home runs in a year. The billions now being spent worldwide on enhancing athletic achievement are a shameful commentary on humanity's priorities."73

This state of affairs is in direct contradiction to a life oriented toward God through the care for the poor. There is also no sign that this inequity is disappearing; new data points out that just 62 people in the world have wealth that is equal to all the wealth put together of the poorest $50 \%$ of the world. The richest $1 \%$ have more wealth than the other $99 \%{ }^{74}$

The ethical directives concerning riches, poverty, and generosity found in James speak directly to this sort of disparity and it is a disparity that Christians need to address if they are to faithfully embody God's word from the book of James, such as care for the orphan and widow and sharing with those in need.

Though the latest and most controversial biotechnologies receive the limelight, a conversation concerning these issues has been springing up among bioethicists. In fact, some bioethicists feel that issues such as embryonic stem cell research, gene therapy, cloning, and posthumanism have garnered too much attention.

Leigh Turner, assistant professor in the biomedical ethics unit at McGill University notes that these issues need to be kept in perspective when looking at the reality of the health needs of the poor:

Greater consideration of global ethical issues related to health, illness, and suffering might generate a richer, more meaningful research agenda for bioethics. Otherwise bioethics risks becoming a source of entertainment and

\footnotetext{
72 Joel Shuman and Brian Volck, Reclaiming the Body: Christians and the Faithful Use of Modern Medicine (Grand Rapids: Brazos Press, 2006), 110.

${ }_{73}^{73}$ C. Ben Mitchell et al., 125-126.

${ }^{74}$ Ben Hirscher and Noah Barkin, "A World Divided: Elites Descend on Swiss Alps Amid Rising Inequality”, accessed March 18, 2016, http://www.reuters.com/article/usdavos-meeting-divisions-idUSKCNOOW007.
} 
spectacle in wealthy societies whose inhabitants overlook the poverty and suffering found throughout most of the world. ${ }^{75}$

Turner's concerns exhibits one of the social ethic touchstones that Johnson noted the book of James provides for contemporary issues. ${ }^{76}$ Turner is not taking a "biblical stance" here, but his concerns reflect the issues of wealth and poverty about which James writes.

Norman Daniels also argues that bioethics is too narrowly concerned with "exotic technologies," such as gene therapy. This fixation neglects elements that impact health more extensively. Daniels states that the agenda of bioethics needs to be more inclusive in regards to distributive justice. ${ }^{77}$ In addition to advocating prominent attention to the economic variable, some bioethicists, such as Lisa Sowle Cahill, maintain that U.S. bioethics “...needs to restructure its philosophical framework and expand its moral criteria to consider how to define a global ethics. ${ }^{78}$ Cahill argues that individualism has been a predominant factor in framing discussions on bioethical issues.

The concerns of Turner, Daniels, Cahill, and others about distributive justice demonstrate congruence with James' ideas concerns for taking care of those in need. They also show that the discipline of bioethics must further investigate and respond to these issues. The "how" of implementation of distributive justice in a global context of health inequities is challenging and complex. Accurate analysis and understanding of economics in a global context does not guarantee that "reasonable" people will agree about what exactly to do. ${ }^{79}$ In spite of the difficulties, the effort to counter these inequalities must be undertaken. The biblical concept of stewardship as applied to a global bioethics can play an important an active part in these discussions.

The goal of bioethicists in these discussions should not be to abandon engagement with problematic biotechnologies. Both global health care needs and issues with biotechnologies need to be addressed. $^{80}$ It is imperative, however, that Christians refuse to show partiality by excessive attention to the "exotic technologies," which are

${ }^{75}$ Leigh Turner, "Bioethics Needs to Rethink Its Agenda," British Medical Journal, 2004 (17 January) 328:175, accessed August 22, 2007, http:/www.bmj.com/cgi/ content/full/328/7432/175

${ }^{76}$ Johnson, 164.

77 Daniels, 22-35.

${ }^{78}$ Lisa Sowle Cahill, "Biotech and Justice: Catching Up with the Real World Order," Hastings Center Report 33, no. 4 (2003): 34.

${ }^{79}$ Daniels, 22- 35. See especially pp. 25-27, 31 .

${ }^{80}$ Timothy Murphy and Gladys B. White, "Dead Sperm Donors or World Hunger: Are Bioethics Studying the Right Stuff?" Hastings Center Report 35, March-April (2005) inside back cover. 
or will be available mostly to the wealthy, at the expense of the basic healthcare needs of the poor, the widow, and the orphan. "The goal for Christians is not a world where everyone can afford cosmetic surgery or use medical technology in purely individual terms, but rather a community where our webs of connection are recognized and nurtured." ${ }^{81}$ This exemplifies the kind of community that James points to when he writes about facing suffering and trials with the wisdom of God, as well as directing both words and actions with wisdom.

Believers need to show through actions and words that they are aligned with God, not the world. Each member of the Body of Christ needs all the other members others to help combat the temptation of using biotechnology in ways that are inappropriate for, “... only by living as the body can we begin to resist [the powers of this world such as medicine]. We will, at times, fail-that much is certain this side of the grave-but God forever calls us back to the gathered body, where we hope to be supported, hope to gather strength, hope to be witnessed to and to witness." ${ }^{82}$ Christians can live a counter cultural witness by practicing an "ethic of limits" when a biotechnology does not dovetail with kingdom goals of justice and love. ${ }^{83}$

Through an "ethic of limits" and care for both those inside and outside of their faith communities, Christians can stand as a visible counter-witness to the world system that worships mortality, medicine, and materialism. Joel Shuman and Brian Volck in their book, Reclaiming the Body, critique the church's and culture's interaction with modern medicine, and call Christians back to theocentric understanding of both the human body and the Body of Christ. ${ }^{84}$ When we care for one another, in health, in sickness, in prosperity, in poverty, the world will take notice; Jesus said "By this all men will know you are My disciples, if you have love for one another." As James clearly teaches, the faith of Christians manifests itself through care for the physical needs of others.

Care for the poor, orphan, and widow are avenues through which the living witness of the church can challenge the ethos of modern culture. Considering all these needs around the globe can be quite overwhelming, but the community of Christ can aid one another as each

\footnotetext{
${ }^{81}$ Joel Shuman and Brian Volck, Reclaiming the Body: Christians and the Faithful Use of Modern Medicine (Grand Rapids: Brazos Press, 2006), 107.

${ }^{82}$ Ibid., 93. Shuman and Volck consider medicine a "power" in the biblical sense. Though I think that medicine is something that the powers use rather than a power itself, I agree with the general tenor of this quote.

${ }^{83}$ Stassen and Gushee, 254; Dennis P. Hollinger, Bioethics Nexus: The Future of Healthcare, Science, and Humanity, BE/BIO 775. Class Notes, July 12, 2007.

${ }^{84}$ Ibid., 31, 41-62, 69. cf. C. Ben Mitchell, et al., 157.

${ }^{85}$ John 13:35.
} 
member uses the gifts God has given them, "Knowing where and with whom to begin requires wisdom, discernment, and ultimately a choice, recognizing that faithful Christians may be called to different particular needs. What is important is to ground each response in the community while acknowledging the diversity of the body." 86 The Body can help Christians decide in what capacity his or her body is called to minister to other bodies.

In 5:1-5, James alludes to Jesus' words about the futile nature of earthly treasure. That message is one that Christians need to embody on an everyday basis. They need to "Just Say No" to things that moth and rust will destroy and thieves break in and steal. ${ }^{87}$ Laying up treasures in heaven involves using time, treasures, and talents to provide basic needs to those who are close to God's heart: the poor, the orphan, and the widow (Jas 1:27; 2:1-16). Saying "no" to the thief, such as television or busyness that steals time, frees Christians to give of their time to visit the ill and elderly, serve in a soup kitchen, or dig a well on a mission trip. Saying "no" to the moth of materialism, that eats up money, frees Christians to give of their treasures to bring malaria medicine, a flock of chickens, and the good news of Jesus to those in need. Saying "no" to the rust of egoism, which corrodes the sense of community, frees Christians to share their talents to use nursing skills on a mission trip, educate others about global stewardship, and embody and verbalize the love of Christ. $^{88}$ Furthermore and very practically, in an age of ever-increasing consumerism all around the world, even in poorer countries, believers need to ask themselves questions like "Is an upgrade to a new cell phone really necessary?", "How much of a data plan do I really need?"

Some may be skeptical about whether or not attitudes, habits, and actions, personal or corporate, can have any impact in a global context. In addition to offering some structural strategies for addressing the needs of those who live on just two dollars a day, Van Til challenges Christians with some very practical examples of how they can have a global impact. For about $\$ 200$ a year a person can give basic sustenance to a family that lives in poverty. Furthermore, a tax or donation of onehundred dollars a year by each adult (about 600 million) in a developed nation would go halfway to getting rid of poverty. ${ }^{89}$ Christians cannot allow geographical or socioeconomic distance to blind them to the needs, for the Body of Christ knows no borders. ${ }^{90}$

\footnotetext{
${ }^{86}$ Shuman and Volck, 92.

${ }^{87}$ Bauckham, 196-203.

${ }^{88}$ Some of the inspiration for these ideas came from Shuman and Volck, 107.

${ }^{89}$ Van Til, 159-161.

${ }^{90}$ Shuman and Volck, 94-107.
} 
While many examples exist where the Body of Christ knows no borders, one the author became familiar with a few years ago is in Koutiala, Mali, West Africa. People from around the world are practicing God's kingdom values of justice and love by ministering to the needs of the poor. On May 22, 2006 Koutiala Hospital for Women and Children opened. The hospital ministers to the spiritual and physical needs of the area's women and children in a country where infant mortality and maternal death are all too common, and access to adequate medical care all too uncommon. Not only is the medical staff participating in this practice of justice and love, but people across the world are practicing global stewardship to start and keep the hospital going. ${ }^{91}$

For example, Shelby Alliance Church, Shelby, Ohio, has been partnered with the Koutiala Hospital project. Their small but mighty Alliance Women, a missions support group, facilitate the sending of supplies to the hospital. They have a list of needed supplies on their website ranging from 9-volt batteries to five-hundred dollar oxygen concentrators. As of April 2007 they had sent out four shipping containers, each filled with hospital supplies that had been donated or purchased. Story after story is told on their website of God's gracious provision, including a hemoglobin meter that was donated by a medical supply company from Russia! ${ }^{92}$

Mali's model, and the evidence of faith worked out through kingdom deeds of love and justice, replicates itself in dozens of places around the world on both large and small scale. Christians also need to replicate this in their lives as they seek to be both wise hearers and doers of God's word. James uses vivid word pictures to exhort Christians to follow God's wisdom through trials and suffering, speech toward others, a proper attitude toward wealth and poverty, and care for those in need. Another literary work helps Christians to envision, that by setting their compass toward God, even in the "small things," they can make great waves in the world. Dorothea Brooke, protagonist of George Eliot's great novel, Middlemarch desired to have a noticeable and great impact for the good on those around her, but her life did not quite work out as she thought it would. Even though she did not achieve a "great work," she did create a lasting influence:

Her full nature, like that river of which Cyrus broke the strength, spent itself in channels which had no great name on the earth. But the effect of her being on those around her was incalculably diffusive: for the growing good

${ }^{91}$ Koutiala Hospital, accessed September 6, 2007, http://www.koutiala hospital.org

${ }_{92}$ Shelby Alliance Church, accessed September 6, 2007, http://www.shelby alliance.org/asp/mali_supplies.asp 
of the world is partly dependent on unhistoric acts; and that things are not so ill with you and me as they might have been, is half owing to the number who have lived faithfully a hidden life, and rest in unvisited tombs. ${ }^{93}$

Though some may have "big parts" to play in engaging the culture in bioethical issues, others will be like Dorothea, remaining faithful in challenging circumstances and exerting influence on those around them. Whether one's part is big or small, the book of James calls all in the community of believers to steward the resources the Lord has given them through generous sharing to those in need. Through personal giving, church involvement, and even working together with people of other cultures and beliefs, Christians can have act in faithfulness to God's commands to love and care for the poor. These waves of generosity that go out from Christians' homes and churches to community, nation, and world can impact even as far away as a hospital in Mali or a village in the remote part of Indonesia.

\section{Bibliography}

Adamson, James. The Epistle of James. The New International Commentary on the New Testament. Grand Rapids, MI, 1976. Reprint, Grand Rapids, MI: Eerdmans, 1984.

Basu, Tanya. "How Many People in the World are Actually Poor?"The Atlantic. Accessed March 21, 2016. http://www.theatlantic.com/ business/archive/2014/06/weve-been-measuring-the-number-ofpoor-people-in-the-world-wrong/373073/

Bauckham, Richard. James: Wisdom of James, Disciple of Jesus the Sage. New Testament Readings. London/New York: Routledge, 1999.

Cahill, Lisa Sowle, "Biotech and Justice: Catching Up with the Real World Order." Hastings Center Report 33, no. 4(2003): 34-44.

Corbett, Steve and Brian Fikkert.When Helping Hurts: How to Alleviate Poverty Without Hurting the Poor or Yourself. Chicago: Moody Publishers, 2009.

Daniels, Norman, "Equity and Population Health: Toward a Broader Bioethics Agenda," Hastings Center Report 36, no4 (2006):22-35.

Davids, Peter. Commentary on James. New International Greek Testament Commentary. Grand Rapids, MI: Eerdmans, 1982.

Fee, Gordon D. and Douglas Stuart. How to Read the Bible for All Its Worth. $3^{\text {rd }}$ edition. Grand Rapids, MI: Zondervan, 2003.

${ }^{93}$ George Eliot, Middlemarch (Ware, UK: Wordsworth Classics, 1994), 781. 
Gundry, Robert H. A Survey of the New Testament.4th edition. Grand Rapids, MI: Zondervan, 2003.

Hay, Donald A. Economics Today: A Christian Critique. Grand Rapids, MI: William B. Eerdmans Publishing Company, 1991.

Hirscher, Ben and Noah Barkin. "A World Divided: Elites Descend on Swiss Alps Amid Rising Inequality."Accessed March 18, 2016. http://www.reuters.com/article/us-davos-meeting-divisionsidUSKCNOOW007.

Hollinger Dennis P. Bioethics Nexus: The Future of Healthcare, Science, and Humanity. BE/BIO 775. Class Notes, July 12, 2007.

Johnson, Luke Timothy. The Letter of James: A New Translation with Introduction and Commentary. The Anchor Bible vol. 37A. New York: Doubleday, 1995.

Koutiala Hospital. Accessed September 6, 2007, http://www.koutiala hospital.org.

Laut, Rimba. "Orang Indonesia HabiskanRp 10 Juta per Tahun untuk Beli Gadget, October 2, 2015.” Accessed March 18, 2016, http:www.ift.co.id/news/tekno/mobile/orang-indonesia-habiskanrp-10-juta-per-tahun-untuk-beli-gadget.

Mitchell, C. Ben, Edmund D. Pellegrino, Jean BethkeElshtain, John F. Kilner, and Scott B. Rae, Biotechnology and the Human Good. Washington, D.C.: GeorgetownUniversity Press, 2007.

Moo, Douglas J. The Letter of James. The Pillar New Testament Commentary. Grand Rapids, MI/Cambridge, U.K.: William B. Eerdmans, 2000.

Mullard, Asher. "Robust Biotech Sector Increases R\&D Spend." Nature Reviews Drug Discovery 14, 449 (July 1, 2015). Accessed March 21, 2016. http://www.nature.com/nrd/journal/vl4/n7/full/nrd4687.html

Murphy, Timothy, and Gladys B. White. "Dead Sperm Donors or World Hunger: Are Bioethics Studying the Right Stuff?" Hastings Center Report 35, no. 2 (March-April 2005).

Pellegrino, Edmund. Plenary 8. "Changing Times." Neuroethics: the New Frontier. $13^{\text {th }}$ Annual Conference on Bioethics, Trinity International University, Deerfield, IL. July 15, 2006.

Shelby Alliance Church. Accessed September 6, 2007. http://www.shelby alliance.org/asp/mali_supplies.asp.

Shuman, Joel and Brian Volck. Reclaiming the Body: Christians and the Faithful Use ofModern Medicine. Grand Rapids: Brazos Press, 2006.

Sider, Ronald J. Just Generosity: A New Vision for Overcoming Poverty in America. Grand Rapids, MI: Baker Books, 2007.

Stassen, Glen H. and David P. Gushee. Kingdom Ethics: Following Jesus in Contemporary Context. Downers Grove: InterVarsity Press, 2003. 
Syebubakar, Abdurrahman "Indonesia Witnesses Rising Poverty", The Jakarta Post, October 8, 2015.Accessed March 21, 2016. http://www. thejakartapost.com/news/2015/10/08/indonesia-witnesses-risingpoverty.html.

Turner, Leigh. "Bioethics needs to rethink its agenda," British Medical Journal, 328 (7432), 175(2004). Accessed August 22, 2007. http://www.bmj.com/content/328/7432/175.1.

Van Til, Kent A. Less Than Two Dollars a Day: A Christian View of World Poverty and the Free Market. Grand Rapids, MI/Cambridge, UK: William B. Eerdmans Publishing Company, 2007.

Vaswani, Karisma. "Indonesia's New Mega-rich Spend it Big as Inequality Grows", August 1, 2014. Accessed March 21, 2016. http://www.bbc.com/news/business-28570422.

Wikipedia, "Biotechnology." Accessed March 21, 2016. https://en. wikipedia.org/wiki/Biotechnology. 